\title{
Potted, Blooming Dendrobium Orchids
}

Ken W. Leonhardt

D epartment of Tropical Plant and Soil Science, College of Tropical Agriculture and $\mathrm{H}$ uman Resources, U niversity of $\mathrm{H}$ awaii at $\mathrm{M}$ anoa, $\mathrm{H}$ onolulu, $\mathrm{H}$ awaii 96822

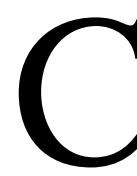

ultivation of potted, blooming dendrobium orchids (D endrobium Swartz.) is a rapidly growing, multimillion dollar activity in the U nited States. The $\mathrm{U}$ niversity of $\mathrm{H}$ awaii has assisted this industry in $\mathrm{H}$ awaii with research on culture and management, and the introduction of a variety of cultivars.

Environmental conditions favored by dendrobium cultivars to be used for pot plants include bright sunlight, warm temperatures, good air movement, and clean water. Plants grow and flower best when night temperatures do not drop below 18 ${ }^{\circ} \mathrm{C}\left(64^{\circ} \mathrm{F}\right)$ and day temperatures are between 24 and $30^{\circ} \mathrm{C}\left(75\right.$ and $\left.86^{\circ} \mathrm{F}\right)$. In $\mathrm{H}$ awaii, dendrobiums are grown mostly in shadecloth-covered structures.

Shadecloth densities vary depending on the solar radiation intensity of the area. In areas where rainfall exceeds $10 \mathrm{~cm}$ (3.9 inches) monthly, best results are obtained in structures with a solid roof covering, as plants and flowers are subject to fungal and bacterial diseases. $\mathrm{N}$ atural or artificial air movement helps keep plants and flowers dry and less subject to pathogens.

Cultivated dendrobium orchids, whether seedlings or clones, are started in aseptic flasks. Plantlets thrive in flasks, but should be deflasked before depletion of nutrients in the agar medium. Proper care of plants from flasks through the community pot or plug tray stage is critical to optimum growth, development, and productivity. D eflasked plants are placed in a pathogen free medium having good moisture holding capacity, drainage, and aeration. Several materials are commercially available, some requiring pasteurization. Young plants should be placed on highly sanitized benches.

Transplanting is normally done to 6 - to $10-\mathrm{cm}$ (2.4- to 3.9 -inch) pots in a relatively coarse medium that promotes rapid root activity, drainage, and aeration. $\mathrm{N}$ utrients in solid and/ or liquid form are adequately provided. The full paper provides a table of recommended ranges of nutrients in leaf tissue. I rrigation is provided early to midday. Foliage and flowers should be dry during nighttime. Certain plant growth regulators may be effective in controlling plant height and in stimulating flowering.

The $\mathrm{U}$ niversity of $\mathrm{H}$ awaii has introduced over 15 dendrobium cultivars for potted plant production. They are products of a breeding system known as genome breeding. M ost are triploids or tetraploids, usually with one amphidiploid parent. Amphidiploids are tetraploids with a complete diploid genome complement from each species parent. This condition causes the amphidiploid to breed as if it were a spe- 
cies, with the resulting narrow genetic diversity normally associated with a species population. When an amphidiploid is crossed with a species or another amphidiploid, the hybrid progeny is relatively uniform from seed.

Genomes, or chromosome sets, are symbolized by letters that indicate the taxonomic section to which the species belong. D endrobium phalaenopsis Fitzgerald and D. bi gibbum F. M ueller are from section Phalaenanthe, represented by "P." These have large, fully shaped flat flowers on medium-length sprays. D endrobium antennatum Lindley and D. strati otes R chb. f. are from section Spatulata, represented by " $C$ " (retained for the former section name, C eratobium). These are vigorous plants that produce abundant sprays with many small flowers having two twisted upper petals (antelope-type). D endrobi um macrophyllum A. Richard and D. spectabile (Blume) M iquel, with uniquely shaped, long lasting, heavy textured flowers, are in the Latourea section (" $L$ " genome), while D. canaliculatum $R$. Brown and D. carronii Lavarack and C ribb of the section Eleutheroglossum ("E" genome) are floriferous, small, compact plants with small twisted flowers.

The various genomes have been combined in many ways to produce a wide assortment of cultivars with distinctive characteristics. The $\mathrm{U}$ niversity of $\mathrm{H}$ awaii released potted plant cultivars by registered name, color, and genome combination, i.e., PC, CC, PPC, PPL, PPE, PCL, PCE, PPCC, PPPC, PCCC, PPPE, etc., will be presented. The numerous $\mathrm{U}$ niversity of $\mathrm{H}$ awaii dendrobium cutflower cultivars (most are PPCC) are also widely grown as flowering potted plants, although they are larger, less compact plants. Seed-propagated dendrobiums have the advantages over mericloned cultivars in that they are easier, faster, and cheaper to produce, and are free of viruses. All $\mathrm{U}$ niversity of $\mathrm{H}$ awaii dendrobium cultivars were created by Professor E meritus $\mathrm{H}$. Kamemoto. $\mathrm{M}$ any other cultivars developed by commercial and hobbyist breeders are cloned for commercial production as potted plant cultivars. 